\title{
Nouveau riche, old guard, established elite: Agency and the leadership of Vivendi Universal
}

Nihel Chabrak, Russell Craig \& Nabyla Daidj

\begin{abstract}
We respond to the call for a more balanced view of agency (Tourish, 2014: 88) by presenting an account of the forced resignation of Jean-Marie Messier as CEO of the major French company, Vivendi Universal, in 2002. Messier's ousting arose from a struggle for board control involving an exercise of power that was influenced strongly by kinship relationships, interlocking directorships, and business alliances; and by the interplay between a nouveau riche (Messier), an influential old guard shareholder family (the Bronfmans), and an established elite (of prominent representatives of French business). Collusion between the French business establishment and the Bronfman family created a coalition of interest and a locus of control that managerial and agency theories explain inadequately. We highlight the potential for a reading of class relationships in terms of structuration to foster better understanding of the complexities involved when the board of a major corporation decides to support, or withdraw support for, their CEO. We highlight several context-specific structures and mechanisms that were influential in determining corporate control and CEO agency.
\end{abstract}

\section{Keywords}

Agency, board, control, elites, kinship, networks, structuration theory 


\section{Introduction}

We are motivated by Tourish (2014) to develop a more expansive view of agency. We do so in a context in which agency is defined as 'the capacity [of leaders] to take action' (Tourish, 2014: 80). We confess to having tended, in the past, to attribute excessive agency to the Chief Executive Officer [CEO] of major corporations. Tourish's (2014) analysis has prompted us to rethink. We also answer the call of Collinson (2014) to mitigate the deep-seated tendency in leadership studies to rely on dichotomous thinking, where 'leaders' personas and practices have tended to be privileged and psychological perspectives and positivist methodologies predominate' (p. 39).

We highlight the merit of re-thinking our understanding of leadership dynamics, and how a CEO's agency can be mitigated by structural factors to form new locations of power. Our study offers implicit critique of the stream of research in leadership that attributes excessive agency to the CEO. This is particularly evident in the dominant leadership theory of the past three decades, that of transformational leadership (see van Knippenberg and Sitkin, 2013, for extended analysis and critique). As such, this paper could be associated with the critical leadership studies paradigm. The approach to agency we advocate does not have a dichotomizing impulse. Rather, we use dialectics between agency and structures to emphasise the role of other organizational actors (such as members of the board of directors and their networked associates). While exercising their agency, these other organizational actors create social structures which have the capacity to reduce CEO agency.

In this paper we provide an encompassing view of agency - one that does not conceive agency as absolute, formal, hierarchical and capable of quantitative determination. Rather, we 
view agency as being influenced by what Giddens (1976) calls 'the duality of structure.' We locate our study, generally, in the non-economics (rather than economics) paradigm of agency theory (Shapiro, 2005). We concentrate more on agency theory's political science paradigm (addressing matters of delegation of power and authority) and the sociology paradigm (analyzing how relationships affect control in complex systems). In terms of the 'streams' of agency theory literature identified by Shapiro (2005: 269-70), our focus is applied more to examinations of 'corporate governance and control' than to matters of 'incentive alignment ...[and] compensation policies' or to 'agency problems, agency costs and agency efficacy.'

We use the lens of a case study of the quest for board control of a large French company, Vivendi Universal [VU]. Our focus is on the circumstances that led VU's board of directors to replace Jean-Marie Messier as CEO and Chair in 2002. We aim to provide a 'more balanced view of agency which takes a fuller account of the agency of other actors' (Tourish, 2014: 88) by having regard for their empowerment through particular social structures.

We reveal how the interplay of kinship bonds, interlocking directorships, business alliances and related structures and mechanisms influenced relationships between VU's CEO and its board of directors; and how this interplay affected the company's control dynamics. We use an analytical framework based principally on Zeitlin (1974) and Palmer and Barber (2001), but informed also by Giddens' (1976) structuration theory. We implicate a coalition of influence (comprising an old guard family and an established elite in French business) in the dismissal of Messier as CEO, and in limiting his agency. In the eyes of many, Messier was an unpatriotic nouveau riche (that is, a person from a low social class who had recently become very rich). According to Dickerson (2003: 1045), 'Messier's sin was in part his extraordinary arrogance ... 
[and his systematic] "Americanization" [of] both his French company and, in the process, his role as CEO.'

We draw attention to the limited capacity of agency theory to explain corporate governance behavior and to reflect the wider institutional contexts that affect organizations (Christopher, 2010: 683). The VU case outlines events that do not accord with the agency theory view 'that the board of directors is an information system that enables the stockholders within large corporations to monitor the opportunism of top executives' (Eisenhardt, 1989: 59). Nor does the VU case reinforce the assumption of managerial theory 'that boards of directors universally rubber stamp decisions by top management' (Palmer et al., 1995: 487). We argue that managerialist and agency theories provide inadequate explanations of how agency was exercised in VU. Additionally, we reveal how social structures are constituted by human agency and, at the same time. are the very medium of this constitution. We draw attention to the capacity for agency theory to promote illusions about market sovereignty, democratic capitalism, and the answerability of corporations to their owners (Rowlinson et al., 2006). The VU case shows how conventional thinking regarding the separation of ownership and management in a large corporation can cloud understanding of the effective source and nature of corporate agency.

The leadership of companies such as VU is influenced by a multiplicity of structures and mechanisms. Thus, multi-theoretical explanations of leader behavior are likely to be encompassing and insightful. Accordingly, we investigate the extent to which agency theory and managerial theory explain why Messier was replaced as CEO. In particular, we explore whether the board of directors was effective in monitoring Messier (agency theory) or whether 
Messier was able to manage differences between directors to increase his power and control (managerial theory). Superficially at least, the removal of Messier seems attributable to the action of the board, thereby lending credence to an agency theory explanation. However, we argue that Messier was removed for less apparent reasons: the entrenched modus operandi of the French business establishment; the coalescing actions of a business elite; and the selfinterest of a long established shareholder family. We contend that the structure of interpersonal relations, group dynamics and political intrigue between several directors, shareholders and other influential players, provides a strong plausible explanation for Messier's removal and for the limits of his agency. Such structures and behaviors are treated as a 'black box' by agency theory (Tricker, 2012).

We contribute to understanding leaders by presenting a broader view of agency. We do so in the context of a decision by a board of directors to support, or not support, an incumbent CEO. We show how the power of a CEO is not totally constrained, as functionalists contend. Furthermore, we reveal it is not absolute, as managerialists contend. We argue that the power of a CEO is relative, and that it can be mitigated. We show how the interests of an established elite and an 'old guard' can coalesce through kinship relations, interlocking directorships, and networks of influence. They create social structures that effect corporate control. Our narrative reveals how matters of national pride, personal prestige and social class can influence critical decisions regarding corporate leadership. We draw attention to a setting in which economic capital was not the only factor determining corporate control - social, cultural and symbolic capital were key elements too. 
Our unfolding narrative introduces a cast that includes members of an 'old boy' network of former students of elite French schools, the Grand Écoles, and members of the elite grands corps of the French civil service. They were strongly patriotic businesspersons and politicians with an overriding commitment to maintain French culture, traditions and its 'insider model' of capitalism (Whittington and Mayer, 2000). Many of the 'old boys' were from the finance and banking industries. They were employed in four major networks of influence (centred on the insurance company AXA, and the banks BNP, Credit Lyonnaise and Société Générale). Other major players in our narrative are representatives of North American capital (the Bronfmans).

Our central character, Messier (born in 1956), was an 'old boy' of a prominent Grand École. As a graduate of the prestigious École nationale d'administration [ENA], Messier was a member of an elite in France ${ }^{1}$ - one that was considered to be the 'keeper of the flame' of French capitalism. He had served in the elite grands corps of the French civil service and had strong links with the French finance industry. He shared a middle class background ${ }^{2}$ with some major influential establishment figures in France. Nonetheless, he was regarded widely by the French business and political establishment as a nouveau riche or parvenu (that is, as a relative newcomer to a socioeconomic class). The older generation of leaders of the French establishment, such as Bébéar (born in 1935, Chair of AXA, and reputed to be the 'godfather' of French business) and Fourtou (born in 1939), regarded Messier as an upstart who had come 'too far too soon' (Ward, 2002: 210).

The forced resignation of Messier in 2002 and the ensuing re-configuration of VU were controlled indirectly by a group of individuals who were not members of VU's board of directors. Their shareholdings were below widely advocated proprietary cut-off points that are 
claimed to indicate corporate agency or control (variously $20 \%, 10 \%$, and $5 \%$ ). We contend that control of VU was won because social structures and mechanisms allowed the established elite in France to collude with an influential 'old guard' family (the Bronfmans) and to create a locus of control that managerialism and agency theory each struggle to identify and explain. Messier's removal as CEO represented the exercise of power 'to achieve one's subjective interests over others' subjective interests' and to 'keep certain interests from getting on the agenda' (Ron, 2008: 272; see also Lukes, 2005).

We do not provide a comprehensive operational micro-analysis of the inner sanctum of corporate power and leadership. Rather, we analyse the dynamic interrelationship between structures and the agency of elite groups in their struggle for corporate control. We highlight the relationships between relevant social players and reveal how power and influence were exercised in the context of existing social structures.

The following section outlines the facilitative analytical framework we use to elaborate on relevant aspects of managerialist and agency theories. We then outline our research method, before explaining the general business climate in which VU operated, and the broad circumstances of the control crisis at VU. Thereafter, we introduce the key players involved in the quest for control of $\mathrm{VU}$ (nouveau riche, old guard, and an established elite including members of the Institut Montaigne and Club Entreprises et Cités). We then explore the struggle for control by exposing some destabilizing factors that are critical in understanding the exercise of power. In the final section we enter conclusions. 


\section{An analytical framework of corporate agency}

In this section we explore how agency arises, and how it can be empowered or limited. We assume readers are familiar with agency theory and its breadth of interpretation and application. Those wanting a fuller appreciation of agency theory should refer to the assessment and review provided by Eisenhardt (1989), and the overview provided by Shapiro (2005).

The separation of ownership and control and the rise of agency

Control or agency arises through the power to select board members; and thereby, to dictate corporate policy. Such a power is attributed to shareholders by agency theory. Managerialism attributes control to the CEO, in a context of 'managerial capitalism'.

Managerial capitalism was born in the 1920s according to Chabrak (2011) and Davis (2009).

Big corporations began to be run by professional managers. They were less constrained by shareholders who increasingly had dispersed shareholdings. When US bankers largely withdrew from owning large corporations, and members of the general public flooded into the stock market during the 1920s, ownership became increasingly dispersed (Berle and Means ([1932] 1982). Ownership became centrifugal with thousands of anonymous, powerless shareholders each owning no more than a tiny fraction of a company's shares. Meanwhile, corporate control became centripetal, with the accession to power of the 'organization man' (Dahrendorf, 1972).

Managerialism claims that as a consequence of managerial capitalism, control could no longer be exercised by an old guard of founding families, but was exercised by managerial elites (Galbraith, 1989). Mace (1971) describes how corporate executives became ascendant in the 1960s: powerful CEOs determined who were board members, what boards could and could not 
do, what information the board received, and how much senior executives (including themselves) were paid. Because top managers had the capacity to nominate a compliant board of directors and to abrogate control by shareholders, the board was viewed as a passive instrument of management control (Galbraith, 1989) and as a legal fiction (Clarke, 2007). Such a shift has been said to eliminate the former capitalist class by promoting a sort of 'capitalism without capitalists' (Dahrendorf, 1972).

For Berle and Means ([1932] 1982), the corporation slipped imperceptibly and inevitably under management control once a cohesive ownership interest with at least a minimum specified proportion of the issued shares disappeared. The specified proprietary control cut-off point of $20 \%$ used in Berle and Means' seminal study in 1932 of the 200 largest US companies has been replaced in more recent research by a $10 \%$ required minimum. However, this revised minimum cut-off point is contestable too: it does not discern some different modes of corporate control that are difficult to categorize (Zeitlin, 1974: 1090). Thus, any conclusion that control shifts to managers when share ownership falls below a specified minimum percentage is, in our view, questionable.

We contend that the claim that agency in modern corporations has shifted from personal property ownership by wealthy families and business dynasties, to business bureaucracies, is overly simplistic. Our analysis in the case of $\mathrm{VU}$ takes account of social structures and mechanisms, and their effect on CEO agency. The structures we examine were created by the pattern of shareholdings and their evolution; the relationships between $\mathrm{VU}$ and other corporations and institutions; and the forms of personal union or interlocking relationship between corporate officers, directors, and principal shareholding families. 
Duality of structure: social structures and the agency of corporate elites

We use Giddens' (1976) structuration theory to explain the relationship between individual actions and social structures. Our readings of Zeitlin (1974) and Palmer and Barber (2001) are informed by Giddens' (1976: 121) ideas of duality of structure: that is, that 'social structures are constituted by human agency, and yet at the same time are the very medium of this constitution' (Giddens, 1976: 121).

According to Palmer and Barber (2001), the position of corporate elites is prescribed institutionally. Corporate elites attain power in a multidimensional social class structure as a consequence of their ownership of the means of production, the social status into which they are born, the educational credentials they attain, and their capacity to network socially with other elites. The desire of self-made corporate leaders to increase their wealth and social status was a strong motivator for the wave of mergers and acquisitions in the 1960s in the USA (Palmer and Barber, 2001). To pursue active corporate acquisition strategies successfully, and to exercise their agency fully, leaders needed to overcome social structures that resulted from the resistance (agency) of other social players (an old guard and an established elite).

The old guard is composed of owning families. They are usually disinclined to engage in diversifying acquisitions (e.g., of the type pursued by $\mathrm{VU}$ ) because of the threat to their current business interests (Palmer and Barber, 2001). The established elite is an inner group that defends the existing social and economic order. It comprises individuals who are embedded in social networks: they attend exclusive schools, frequent exclusive organizations and social 
clubs, and serve on interlocking boards of directors. They do not necessarily come from families of high status (Palmer and Barber, 2001).

Hence, for Palmer and Barber (2001), CEO agency is possible only if it is freed from social structures that result from the exercise of agency by other social actors. We contend that an individual's social actions and agency are the synthesis of structures and agency. Thus, agency is not simply a function of an individual's expression of will. Furthermore, it is not constrained by the incommensurable forces of social structures. Rather, agency is influenced by structures. These structures are not (metaphorical) 'steel frames,' but are socially constructed. They are produced, maintained and adapted through the exercise of agency by social actors.

Zeitlin (1974) offers good account of how the agency of corporate elites creates structures and mechanisms that limit CEO agency. These elites take advantage of interlocking directorships, and other networks, to do so. He argues that the web of kinship relations that unites apparently unrelated individuals forming boards of directors, helps to determine corporate agency and control. He adds that central to developing an understanding of such control is the need to appreciate the connections between directors and banks; and whether a family sphere of influence exists through various personal and business connections, complicated business structures, and other 'eleemosynary [charitable] arrangements' (Zeitlin, 1974: 1098). Consistent with this view, a family-dominated business dynasty can be more resilient than managerialism would suggest. It can exercise control at lower (percentage) levels of proprietary ownership by virtue of strong kinship networks. Thus, a small proportion of shares in the hands of an influential family can carry different control potential than if held by a single individual with no other major resources and supporting institutions (Zeitlin, 1974: 1098- 
99). In this vein, La Porta et al. (1999: 502) provide evidence that 'families often have control rights over firms significantly in excess of their cash flow rights.' Thus, strong family relationships should be viewed as powerful forms of capital, and as having the potential to be critical influences in the quest for control of a company (Bourdieu and Wacquant, 1992).

Drawing on Zeitlin (1974), we argue that some influential social actors (the old guard and the business elite), in their exercise of agency, create structural limitations on CEO agency.

\section{Method}

We embed our study of the leadership change at VU in a deeper study of preceding events. We rely on a wide array of publicly available information, including VU's published annual (and other publicly available) reports, and press releases issued by VU and the French Capital Markets Authority (Autorité des marchés financiers). From these sources we compiled financial and corporate governance data (e.g., VU's capital structure from 2000 to 2004; and the composition of VU's board of directors before and after the resignation of Messier). We used a cartographic approach, similar to that of Chabrak (2012, Table 3), to understand the networks of influence in French capitalism.

Our qualitative research methods (including document analysis procedures) follow the principles outlined by Miles and Huberman (1994): that is, in respect of data reduction, data display, and conclusion drawing and verification. Our method involved observing data related to the phenomenon at issue (the resignation of Messier); developing conjectures to explain that phenomenon (analytical framework); and then collecting data to confirm or refute them (Blaikie, 2007). The first and third authors, as residents of Paris, were first-hand observers of the leadership control crisis at VU. They worked together, independently of the second author, 
to form initial assessments. These were moderated subsequently by the second author, until a consensus view was reached.

Secondary data were accessed from a variety of conventional bibliographic sources, including scholarly journals (some accessed using Google Scholar), Internet websites (e.g., of NYSE Euronext), and French and American newspapers and periodicals (e.g., le Monde, Time, Vanity Fair, and New York Times). We draw contextualizing information from a widely cited biography of Messier by Orange and Johnson (2004) and from a case study of the (so-called) 'rescue' of VU (Rebiere 2004). Secondary data were analysed concurrently with primary data to corroborate the factual content of statements derived from document analysis. Almost all data sources were read separately by at least two authors.

This study's interpretive nature renders it prudent for readers to be mindful that the social situation documented is complex and fraught with a 'plurality of plausible explanations' (Ron, 2008: 291). Thus, we make no claim that the explanations offered are necessarily better than any other. We rely on a conception of objectivity that has been endorsed widely in the social sciences. We recognize that there are no pure facts in social research. Nonetheless, our findings appear to be consistent with our concepts and theorising. Readers should be mindful that knowledge is constructed socially, that the views we present of the social world are a matter of intersubjective agreement; and knowledge is an interpretation which is subject to social controls, criticism by peers, and social negotiation (Blaikie, 2007). Thus, if objectivity is construed as a critically achieved consensus of the scientific community, then our results should be considered tentative and open to revision. 


\section{The control crisis at Vivendi Universal}

Throughout the 1990s, media conglomerates such as VU engaged in cross-industry mergers, acquisitions and strategic alliances to obtain stronger competitive positions. Their actions were facilitated by government deregulation of the telecommunications industry, digitalization in telecommunications, and competition in satellite, cable, analog and digital terrestrial diffusion.

By 2000, the media market in the US and Europe had become dominated by large, integrated, diversified companies (Time Warner, Disney-ABC, Viacom-CBS, News Corp, Sony and Bertelsmann). These companies served diverse audiences through multiple distribution channels and multiple technologies. They acquired complementary assets and pursued vertical integration. They acquired content-production capacity, distribution capacity, and the right to market consumer electronic devices. In 2000, the mergers of Vivendi with Universal (to form VU), and AOL with Time Warner (to form AOL Time Warner [AOLTW]) were prominent examples of global multimedia convergence strategies. However, the VU and AOLTW mergers were both deemed to be failures (Bodie, 2006: 975). To understand the main reasons for the failure of the VU merger, and whether the strategic thinking underlying it was a valid reason for Messier's removal, it is important to first explore how VU developed and expanded.

VU emerged from a French water and waste management utility whose core business had been conducted by Compagnie Générale des Eaux [CGE] since 1853. CGE adopted the name Vivendi in 1998 when Jean-Marie Messier became its Chair. Messier quickly made his mark. In July 2002, he was announced as Time magazine's person of the week. He was portrayed as 'a former water company executive who became a French business celebrity by turning a sleepy water utility ... [CGE] into a \$51 billion global media giant, Vivendi Universal' (Coatney, 2002). 
Messier accelerated CGE's diversification by making significant investments in mobile telephony and new media technologies. Major events in the history of VU are summarized in Table 1.

Insert Table 1 about here

In June 2000, Vivendi acquired Universal Studios in Hollywood through its purchase of the Canadian alcoholic beverages producer, Seagram. This gave Vivendi interests in movie production, cinema operation and music rights. The merged company, Vivendi Universal [VU], became the world's second largest media group after Time Warner. Thus, a French company became owner of a major American movie studio and the world's principal music publisher. The merger made strategic sense because of the vertical integration between content (the contributions of Universal and Canal+ on film, music, fiction, documentary, and video games) and distribution (television, Vizzavi portal, mobile phones). ${ }^{3}$ The integration was intended to develop economies of scope between all divisions of $\mathrm{VU}$ and to take advantage of many strategic possibilities. ${ }^{4}$

Messier's leadership riled the French establishment: it perceived him to be an ambitious, garrulous showman who courted celebrity status (Clark, 2004). For his part, Messier alleges 'prominent members of the French business establishment' conspired against him (Clark, 2004). Messier did not endear himself to many ordinary French people. He confronted French pride and nationalism. He dismissed 'French cultural exception', embraced English as the official language of $\mathrm{VU}$, and advocated the adoption of American business culture (see Dickerson, 2003: 1046).

By 2002, VU had sustained severe financial losses. The 'halo effect' described by Rosenzweig (2007) was at play. VU's good performance in prior years was attributed to its 
allegedly visionary and charismatic CEO. Evaluation of bad performance was biased in a similar fashion. Generally, observers formed an opposite conclusion -the same CEO now viewed as arrogant. The halo effect seems to have lingered, at least partially, because although Messier was blamed for the bad performance, the general strategic direction he set for the company was not implicated by his critics in their blame. Messier's forced resignation as CEO on June 30, 2002 raises many issues regarding corporate agency and control. We contend his resignation was not prompted by strategic mistakes on his part, or by any compelling force of unacceptable accounting performance measures. Rather, we contend it was the consequence of social structures and mechanisms involving kinship relationships, interlocking directorships, and business alliances that resulted from the exercise of agency by corporate elites. In explaining our contention, we focus on a nouveau riche (Messier), an old guard influential shareholder family (Bronfmans), and an established elite (influential directors). ${ }^{5}$

Messier's removal as CEO is analyzed in the context of the long tradition of French companies of sharing the services of their CEOs reciprocally through interlocking board memberships. In 1999, 50\% of French corporations were involved in reciprocal interlocking directorships (Yeo et al., 2003). Persons appointed to two, three, or more corporate boards were part of an inner-circle of elite persons who were more likely to have attended the 'right' schools, belonged to the 'right' clubs, and be from the 'right' social background. In 1995, 23 elite persons held 214 board directorships in France and exerted strong control over companies composing the CAC 40 (Kadushin, 1995: 203).

We identify four networks of influence among the French directors. These centered on the insurance company AXA (founded by Bébéar) and three large banks, as follows: 
- AXA network: including Bébéar, Breton (Thomson), Fourtou (Aventis), Lachman (Schneider), François-Poncet (BNP Paribas).

- BNP network: including Pébereau, Bébéar, (AXA), Beffa (Saint-Gobain), Friedman (UAP), Messier (VU), Owen-Jones (L’Oréal).

- Société Générale network: including Bouton, Tchuruk (Alcatel), Messier (Vivendi Universal), Desmarest (TotalFina-Elf), Viénot.

- Crédit Lyonnais network: including Lagardère (Lagardère), Bouygues (Bouygues).

It is common practice for links between elite educational institutions and major financial and industrial companies to be exploited to protect French corporations from hostile attacks by institutional investors (Whittington and Mayer, 2000). The French elite, from the prestigious Grandes Écoles and les corps de l'Etat, benefited from government-supported institutional arrangements that encouraged cross-shareholdings and interlocking board directorships (Whittington and Mayer, 2000). However, from about the end of the 1990s, the pressure exerted by institutional investors diluted the level of cross-shareholdings (Morin, 2009).

\section{Key Players}

Nouveau riche and old guard

Messier was born into a family of modest status in Grenoble in 1956, the son of a chartered accountant and the grandson of a chauffeur (Orange and Johnson, 2004). He progressed to study at the École Polytechnique (X), and the École nationale d'administration [ENA]. After appointments in the French Economics Ministry during the 1980s, and at the Lazard Frères investment bank in 1989, he joined CGE in 1994, becoming its chair in 1998. (For a fuller 
biography see the oncyclopedia Business, http://www.referenceforbusiness.com/biography/M-R/Messier-Jean-Marie-1956.html).

The established elite frowned on Messier because of the turbulence he instigated. In 2001, Messier's annual income was estimated at $€ 5.1$ million. He flaunted his wealth. He was accused of arrogance and social climbing. His relationship with actress Sophie Marceau, his private A319 Airbus, and his luxurious penthouse in New York, were the subject of many articles in French newspapers and magazines. When in New York, Messier behaved like a show business celebrity, much to the chagrin of the French business elite. He explained his behavior as overcompensation for the shyness he suffered in his youth (Jean-Marie Messier: les six mois de chute, Le Monde, 2 July 2002, http://www.lemonde.fr/). ${ }^{6}$

In 2000 , the creation of VU with a share market capitalization of $€ 100$ billion heralded the arrival on the VU share register of a very wealthy and influential family, the Bronfmans. They had prospered largely because of the business acumen of Samuel Bronfman (1889-1971) and the large fortune he made in Canada in the alcoholic distilled beverage business. Samuel married Saidye Rosner (1897-1995) in 1922. Their four children were all well-connected and influential. $^{7}$ The Bronfmans were substantial philanthropists, committed to advancing social, cultural and educational causes, principally in Canada. They funded the Bronfman Building at McGill University (1971), created the McGill Institute for the Study of Canada (1993), and donated the Seagram Building in Montreal to McGill University (2002). The Bronfman family was also prominent in campaigns to compensate victims of the Holocaust.

Prior to 2000, the family had been the majority owner of Seagram, a diversified conglomerate. However, at the instigation of its CEO, Edgar Bronfman Jr., Seagram expanded 
into entertainment and music. In 2000, it agreed with Vivendi to create Vivendi Universal. As part of this deal, $59 \%$ of Seagram's capital was transferred to shareholders of Vivendi, $12 \%$ became owned by shareholders of Canal+, and $29 \%$ by shareholders of Seagram. Eight per cent of the share capital of $\mathrm{VU}$, and eight seats on the $\mathrm{VU}$ board of directors, were allocated to the Bronfman family. This made them the dominant shareholder of VU in 2000. Importantly, the creation of VU made Edgar Bronfman Jr. and Jean-Marie Messier business associates. Both dreamt of building a world media colossus. Both shared a vision of diversification and expansion into the entertainment industry. They were men of similar ambitions, but from different social spheres.

Edgar Bronfman Jr. had a passion for the entertainment business. At an early age, he was a film and Broadway producer and a songwriter. He was keen to shift Seagram's interests from alcoholic beverages to media. In 1993, based on his advice, Seagram acquired $15 \%$ of Time Warner. In 1995, Edgar Jr. convinced the family to resell his $24 \%$ stake in the DuPont Company to fund the purchase of Universal Studios from Matsushita Electric.

For his part, Messier dreamt of founding a company that 'could be the world's preferred creator and provider of personalized information, entertainment and services to consumers anywhere, at any time and across all distribution platforms and devices' (Coatney, 2002). On 13 October 2000, Messier declared proudly that 'the old Vivendi group had died' and that, because of the merger with Seagram, a French company had entered the 'forbidden city' of Hollywood (Les cinq métiers du nouveau géant, Le Monde, 16 October 2000, http://www.lemonde.fr/). 
Established elites: Institut Montaigne and Club Entreprises et Cités

In 1983, Bébéar (assisted principally by Lachman) created Club Entreprises et Cités to lobby for private enterprise. This 'club' brought together strong supporters of free market ideology. In 1986, with the formation of a right wing government by Jacques Chirac, the club participated actively in the wave of privatizations of major French companies and banks.

The privately funded Institut Montaigne was a self-proclaimed liberal (here meaning proconservative, pro-business) think-tank created by Bébéar in 2000, funded by about 80 French companies. ${ }^{8}$ Institut Montaigne's members included powerful CEOs (such as Lachman, Fourtou and Bébéar), public personalities, academics and representatives of the civil society - all of whom wanted to influence public policy issues in France. The members comprised about 30 of the most influential CEOs in the French business world.

There was strong solidarity between members of Club Entreprises et Cités. At the time of Messier's resignation, five French directors of the VU board were members. In September 2002, when Fourtou, as the newly-installed CEO, sold VU's interests in Canal+ Technologies to Thomson Multimedia for $€ 190$ million, many analysts concluded that the price had been underestimated - a few months later Canal+ Technologies was resold by Thomson Multimedia for a gain of $€ 110$ million. Some analysts have described this as an exchange of gifts between two members of Club Entreprises et Cités, Fourtou and Breton (Rebiere, 2004).

\section{The Control of VU: Beyond three apparent destabilizing factors}

The first apparent destabilizing factor after VU's merger with Seagram was its announcement of accounting losses of $€ 13.6$ billion in 2001 and $€ 23.3$ billion in 2002 . These were then the worst 
ever reported losses for a French company. They were due, in part, to asset acquisitions made by Messier (about $€ 100$ billion), flagging sales revenues, and the bursting of the dot-com bubble in 2000-01. The losses shook investor confidence and raised doubts about the sagacity of VU's convergence strategy. However, in Messier's defence, VU's reported accounting losses were attributable, in part, to a global, industry-wide phenomenon. They were not a primary consequence of Messier's leadership. Indeed, in 2002, VU's major international competitor, AOLTW, recorded a loss of about $\$$ US100 billion - the largest loss ever posted (to that time) by a US company.

The accounting results reported in 2002 by AOLTW and VU reflect the similar problems both companies experienced after the bursting of the dot.com bubble in 2000-01. The return on equity [defined as Reported Net Profit $\div$ Total Shareholders' Funds] for both companies followed a similar pattern over the years 2000 to 2002 :

\section{Return on Equity}

\begin{tabular}{|l|l|l|l|}
\hline Company & $\mathbf{2 0 0 0}$ & $\mathbf{2 0 0 1}$ & $\mathbf{2 0 0 2}$ \\
\hline VU & $4.06 \%$ & $-37.00 \%$ & $-166.00 \%$ \\
\hline AOLTW & $-2.78 \%$ & $-3.25 \%$ & $-186.86 \%$ \\
\hline
\end{tabular}

Published balance sheets for each company reveal a similar collapse in total shareholders' equity during their 2002 financial years: $62 \%$ for $\mathrm{VU}$, and $65 \%$ for AOLTW. In the case of AOLTW, poor financial performance was attributed to the difficulty of achieving synergies between AOL (new economy) and Time Warner (old economy).

In VU's case, the French establishment elite used the poor financial results to campaign for Messier's ousting. However, Messier's ultimate removal was not because his strategy of convergence was folly. Indeed, his ousting did not lead to a change in the company's strategic 
choice of a policy of convergence. A major (though largely unstated) motive for his removal seemed linked to the fact that the merger to form $\mathrm{VU}$ involved a merger with American interests. ${ }^{9}$ This presented important sovereignty issues to the French - issues that were particularly galling in view of the insensitivity of a class-hopping nouveau riche, Messier. Indeed, subsequent to Messier's removal, VU decided to sell its new American assets to focus on core business. However, it did not change Messier's overriding strategic policy. This lends credence to contention that the interests of the Bronfmans and the French business elite coalesced to remove what they regarded to be a dangerous de-stabilizing influence. The Bronfmans wanted to preserve their wealth. The French establishment wanted to preserve French capitalism and culture. Messier's removal was not the result of a market governance mechanism that acted in the way suggested by agency theorists. Rather, it arose more from Messier's role in bringing unwanted turbulence to the established interests of a corporate elite.

The role that the published accounting results played in influencing the board's decision is consistent with the 'ammunition machine' metaphor proposed by Burchell et al. (1980): that is, accounting information was used to support a political process 'by which and through which interested parties [promoted] their own particular interests' (p.15). The organizational setting at VU conformed to many of the characteristics Burchell et al. (1980) suggest coincide with the use of accounting in such a role: there was a conflict over basic orientations and the means to achieve ends; and there were coalitions of interest.

A second alleged destabilizing factor was that rumors and short selling in June 2002 caused a sharp decline in VU's share price. On June 24,2002 , VU shares lost $23.3 \%$, closing at $€ 18.75$. However, this decline should be analyzed in the context that, in 2002, the French stock market 
index, CAC 40 , lost $33.75 \%$. The decline was $19.9 \%$ on June 24 alone. ${ }^{10}$ At a meeting of the board of directors held three days later, Messier was under pressure. ${ }^{11}$ Financial magazines and newspapers accentuated a wave of panic by propagating rumors. Many commentators maintain there was an orchestrated putsch for Messier to resign at the board meeting on June 27, 2002 (La Bourse de Paris au plus bas depuis septembre 2001, Le Monde, 26 June 2002, http://www.lemonde.fr/). Messier resigned three days later.

A third misleading destabilizing factor was that, from the first half of 2002, the board of directors (see Table 2) announced its concern about the failure of VU to realize the expected synergies of its convergence with Seagram.

Insert Table 2 about here

The board declared that it had negotiated additional financial facilities from banks on June 28. Those negotiations were made easier because Société Générale and BNP Paribas were committed heavily to VU; and because two directors of VU were honorary presidents of these banks (Thomas at BNP Paribas; Viénot at Société Générale). However, and importantly, the financial facilitation VU received was made on one condition: that Messier should resign. ${ }^{12}$ This pressuring tactic was applied by the French business elite. They campaigned to persuade the VU board that it would never get operational control of American assets; and that those assets should be sold to American interests to preserve Vivendi Environnement (that is, CGE). ${ }^{13}$

Messier's agency and the agency of an established elite and old guard: duality of structure Fourtou's appointment as CEO was the culmination of a putsch orchestrated by the Bronfman family and Bébéar. This was facilitated by the kinship of apparently unrelated directors. As 
shown in Table 3, VU's board of directors was dominated by members of the Club Entreprises et Cités, a conservative business lobby group. The agency of the Bronfman family and Bébéar imposed structural limitations on Messier exercising his agency fully.

Insert Table 3 about here

The influence of the Bronfman family cannot be appreciated fully if we use the managerialist criterion of $10 \%$ of share ownership as the indicator of control. It would be better to establish their control by using Burch's (1972) criteria: family members were affluent and held $4 \%$ to $5 \%$ or more of the voting shares; and family members were on the board of directors over an extended period of time (see Table 4).

Insert Table 4 about here

However, regardless of their small proportion of VU's shares, we argue that the Bronfman family's agency became a decisive factor in creating structural limitations on Messier's agency and his capacity to effect VU policies and its reconfiguration. This is particularly the case when their interests and actions coalesced with those of Bébéar and his factional allies on the board. Although VU's directors were apparently unrelated individuals, in reality they were connected by close kinship relations. This empowered their agency and their capacity to influence Messier. In accord with the explanation given by Zeitlin (1974; 1989), VU directors were either from (or associated with) large banks and insurance companies. Generally, in France, large banks and insurance companies hold stakes in large corporations and are represented on boards of directors. Those boards also contain many influential individuals and families as principal shareholders. Thus, they often contain a small circle of persons with the capacity to exert concentrated power because of their community of interests. 
In 2001, under Messier's leadership, there were 19 directors. The 12 French directors included some very influential personalities in the French business world (see Table 2). The large VU board made it easier for Messier to manage any antagonism and reinforce his control. At this time, Messier was at the heart of a network of 39 directors and some loosely coupled sub-networks (Guieu and Meschi, 2008). However, after his resignation in 2002, the only significant network that remained was composed of Pébereau, Fourtou, Breton, Roger, Bébéar, Roulet, Poncet, Friedmann, Calvet and Lachmann (Guieu and Meschi, 2008). Bébéar, Friedman and Pébereau were members of the French finance industry. Lachmann, the former CEO of Schneider Electric, was a close friend of Bébéar and Chirac and shared a love of rugby with Bébéar. Of the other French members of the board in 2003, Bébéar, Fourtou and Collomb had each attended École Polytechnique $(X)$, the most prestigious school in the unique French system of Grandes Écoles. ${ }^{14}$ Attendance at this school had a history of leading to membership of the elite grands corps of the French civil service (Corps des Mines, Conseil d'État, Cour des comptes and the Inspection générale des finances) - breeding grounds for the 'inner group' (Kadushin, 1995; Campbell 2014).

Two other factors were critical in defining friendships in the inner group: political tendencies, and class solidarity (Kadushin, 1995). Messier's replacement, Fourtou, had been a close friend of Bébéar for more than 30 years. ${ }^{15}$ Fourtou and Bébéar were born and raised in Gascogny in the south-west of France. They shared common passions for gastronomy, wine and rugby. Bébéar successfully championed Fourtou to succeed Messier in spite of opposition from the Corps des Inspecteurs de Finance, a state audit supervisory body. 
Lachman, Fourtou and Bébéar had many influential friends in common, including Serge Kampf (Capgemini), Michel Pébereau (BNP Paribas), Thierry Breton (former CEO of Thomson and France Télécom), Daniel Bernard (former CEO of Carrefour), Gérard Mestrallet (Suez), and Martin Bouygues (Bouygues). These friends had many opportunities to caucus informally and to discuss business-related matters. They often met at the opera or the theatre. Every winter the many rugby fans among them were invited by Serge Kampf and Pierre Dauzier, ex-owner of Havas (a multinational communications group), to fly in private jets with the former champion rugby player, Jean-Pierre Rives, to watch Six Nations Championship rugby games. ${ }^{16}$ Many dined together regularly. The choice of Fourtou to replace Messier was unsurprising in view of findings that boards are likely to appoint CEOs who 'resemble themselves' so as to be able to 'rely on demographic similarity as a way to reduce [performance] ambiguity and [social] uncertainty' (Zajac and Westphal, 1996: 84).

The Bébéar clan, an arm of the established elite, was committed to the good functioning and protection of French capitalism. Members of the clan viewed Messier as a threat to their interests because he had been prepared to dispense with established cultural and economic values to pursue a broader strategy of global convergence. ${ }^{17}$ The turbulence he brought to the Parisian business world was viewed as dangerous and his agency (his capacity to act) was inhibited by the structures resulting from the established elite and the old guard exercise of agency.

The replacement of Messier 
Throughout the period of destabilization, Messier disregarded criticism of his leadership. He presented VU's poor reported accounting performance as a logical consequence of the bursting of the dot-com bubble. He held Canal+ responsible for the group's poor financial performance and forced its popular CEO (Pierre Lescure) to resign on 16 April 2002. However, the firing of Lescure 'wakened a sleeping giant in the form of venerable French businessman Claude Bébéar, who decided that urgent intervention was needed ...' (Ward, 2002: 210).

Although Messier had managed cultural differences between the North American and French directors well for two years, in 2002 he became overly confident. During the 2002 General Assembly, President Chirac stated publicly that Vivendi Environnement should remain French. Messier committed to do so. However, Messier reneged, despite concerted pressure by the Minister of Finance (Laurent Fabius), and lobbying by André Santini (trade union leader) and Jean-Paul Delevoye (President of the Association of French Mayors). VU's ownership of Vivendi Environnement fell to just below $50 \%$ in April 2002, and to $20.4 \%$ in December $2002 .{ }^{18}$ Two days after Messier resigned as CEO, Chirac declared that Messier was no longer a 'desirable person' in the Elysée. ${ }^{19}$

Messier's tenure as CEO was rendered fragile by a significant change in the internal dynamic of the board. On 27 June 2002, with the share price in decline, a strong supporter of Messier, Bernard Arnault (CEO of LVMH), resigned. This compounded Messier's difficulties in controlling the board because four other directors who had supported him (Jean-Louis Beffa, René Thomas, Philippe Foriel-Destezet and Pierre Lescure) had left the board earlier in the year. The board was now balanced evenly with 7 French directors (including Messier) and 7 foreign directors. This encouraged the foreign directors to propose Messier's replacement by Edgar 
Bronfman Jr.. Messier's response was to appeal to French patriotism by brandishing the French flag (metaphorically) in the face of the Bronfman family. He rallied the French directors to protect the company's French interests (Rebiere, 2004).

Messier's numerous enemies were very concerned about his insensitivity to Gallic pride and culture. His declaration that English should be VU's official language and his advocacy of American business culture for VU, were highly inflammatory (Ward, 2002: 209). His view that this 'French cultural exception' was outdated was at odds with the deep rooting of this principle in French psyche. It dismayed many French people, including many in the French entertainment industry, and French President Jacques Chirac (Coatney, 2002; Ward, 2002: 209). However, perhaps worse was Messier's announcement before the French Federal Communications Commission that he would discontinue funding support for the French cinema.

Seemingly convinced that the century-long dynasty built by Samuel Bronfman was about to crumble because of the fall of VU's share price, the Bronfmans started regarded Messier and his convergence strategy as a suitable scapegoat for their ills. ${ }^{20}$ They allegedly asked an American law firm (Wolf Haldenstein Adler Freeman and Herz) to inform the French directors of VU that they risked a class action lawsuit against them if they continued supporting Messier, while their actual strategy was to conspire with them (notably Bébéar allies in the board) to remove Messier as CEO.

After a board meeting on 29 May 2002, a governance committee was created, co-chaired by Edgar Bronfman Jr. and Marc Viénot (a French director co-opted by Messier). At the same time, Samuel Mintzberg (a board representative of one of two branches of the Bronfman family) collaborated with Bébéar to orchestrate Messier's resignation. Mintzberg advised 
Bébéar that the Bronfman's had agreed that Jean-René Fourtou should replace Messier (Rebiere, 2004). In their compaign against Messier, the Bronfmans and Bébéar were supported by the two French directors of VU who were factional allies of Bébéar (Jean-Marc Espalioux [Accor] and Henri Lachmann [Schneider]).

On June 27, the French directors met after being informed that Moodys intended to lower the rating of $\mathrm{VU}$ securities to junk bond status. During this meeting, Marc Viénot and Jacques Friedman changed their allegiance: they no longer supported Messier. Serge Tchuruk, the CEO of Alcatel was the last director to support Messier. The board of directors asked Messier to resign as CEO in favour of Fourtou (whose appointment had been supported by the cabinet of Prime Minister, Raffarin). Messier resigned on June 30, 2002 on condition that he be awarded $\$ 20$ million to help refund a loan of \$25 million he had taken out to purchase shares of VU (Rebiere, 2004). Fourtou, a close friend of Bébéar, was then appointed CEO of VU. Bébéar was put in charge of the Finance Committee. Lachman was appointed to chair the Strategy Committee. Members of the influential Club Entreprises et Cités now dominated the board of directors.

Fourtou disposed of some non-strategic assets of VU. This yielded $€ 24.6$ billion in three years. ${ }^{21} \mathrm{He}$ invested $€ 24.1$ billion in other businesses. The group reduced its net financial debt by about $€ 20$ billion. VU continued to be a major company in media and telecommunications. Importantly, Fourtou did not change the strategic orientation Messier had adopted - apart from transferring $80 \%$ of VU's interests in Vivendi Universal Entertainment to NBC in 2004. This reduced VU's financial debt by a further $€ 5.3$ billion and gave VU a $20 \%$ interest in NBC, valued at $€ 4.9$ billion (VU annual reports for 2002, 2003, 2004, http://www.amf-france.org/). 


\section{Conclusions}

This paper can be located in that part of the leadership literature which contends that corporate power and agency is not concentrated absolutely in the hands of leaders, but is dispersed widely, and can be marshalled by non-leaders and leaders (Tourish, 2014, p.80). As such, an implicit message is that we should be less inclined to view leaders as at the "centre of more or less solid hierarchies and stable networks", but instead regard their agency as ephemeral, and fashioned by "fluid social structures" and "particular social, organisational and temporal contexts" (Tourish, 2014, pp. 79-80). We alluded in the opening of our paper to the leader-centric accounts of agency that are a key feature of transformational leadership theories. In even more blatant form, such approaches feed into populist narratives that seek to identify 'the top performing CEOs' in any given year, and which assume a direct causal connection between CEO intentions and organizational performance (e.g., Ignatius, 2014). Our paper challenges such perspectives. In the VU case, the actions of the old guard and established elite highlight the potential to regard non-leaders "as knowledgeable and proactive agents with multiple prospects for action and deep vestiges of power at their disposal" (Tourish, 2014, p.88).

Messier's removal as CEO of VU reveals how agency can be constrained by social structures and a larger political environment. These constraints can severely disrupt leaders' ability to exercise power, and retain their post. ${ }^{22}$ The VU case provides a more balanced view of agency one that is consistent with Giddens' (1976) 'duality of structure' explanation. We reveal the importance of social structures and mechanisms, such as networks of influence (family, friends, and access to capital), appeals to patriotism, and inflamed prejudices (e.g., against a nouveau 
riche), that result from the exercise of agency by other influential social actors. We draw attention to the limitations of quantitatively deterministic 'rules of thumb' to indicate the locus of effective agency. We highlight the potential for leader agency to be mediated by 'national cultural identity' and entrenched national 'modes of doing business.'

Understanding the forces that influenced the resignation of Messier provides insight to features of corporate agency that have been under-researched. The interests of the old guard Bronfman family coincided with those of the established elite. This commonality of interests shifted the locus of control to the wealthy Bronfman family (despite it owning less than $5 \%$ of the voting share capital) and the Bébéar clan (despite most of its members not being board directors). Thus, the emerging picture is of two groups of capitalists whose interests were mutually dependent and intertwined. They exercised power to shape social and political conditions in a way that suited them.

The joint use of power by an old guard family and an established business elite was instrumental in limiting Messier agency. Each party promoted their subjective interests. The French established elite wanted to keep France free of the polluting effects of Americanization of French business practice, and the abandonment of policies of French cultural exception. The Bronfmans wanted to protect the century-long dynasty built by Samuel Bronfman. Once, they colluded, the resulting structures and mechanisms 'set in motion ... worked quickly' to oust Messier (Ward, 2002: 212).

Understanding of the control struggle at VU should not overlook the importance of the exploitation of class relationships. The $\mathrm{VU}$ case draws attention to circumstances in which economic capital is not the sole determinant of the winners of power struggles. Other forms of 
capital (such as social capital) were crucial in ceding control of VU to persons who did not hold a major interest in the group capital or who were not involved in VU's governance. We should recognize too that financial accounts and reports had diminished revelatory potential. They did not enable potential or existing shareholders, customers or employees to learn much about the tussle for control of the company. As a consequence, many shareholders with large holdings were at an information and power disadvantage - unless, like many of the leading characters in the preceding narrative, they were able to take advantage of 'the right connections.'

In terms of leadership theory and pedagogy, the VU case stresses that leaders are often embedded in, or subject to, dense networks of influence that either inhibit or enhance their agency and capacity for action. This important feature of leadership contexts is often underplayed in theorizing about, and in teaching, leadership. It is important to have regard for the view that individual actions of leaders arise from a synthesis of social structures and agency. 
Table 1. Major Events in the History of Vivendi Universal to 2004

\begin{tabular}{|c|c|}
\hline Date & Event \\
\hline 1853 & Compagnie Générale des Eaux [CGE] forms to supply water in Paris. \\
\hline$>1900$ & CGE diversifies into waste management, transport, energy, real estate and communication. \\
\hline 1983 & CGE participates in the creation of Canal+, the first premium pay TV channel in France. \\
\hline 1987 & Société française de radiotéléphone [SFR] is created. \\
\hline 1998 & Messier becomes Chair of CGE. The group takes the name of Vivendi. \\
\hline 2000 & Vivendi agrees to launch the Vizzavi Internet portal with Vodafone Airtouch. \\
\hline 2000 & $\begin{array}{l}\text { Vivendi Universal [VU] created through a merger of Vivendi's media interests with Canal+ TV networks } \\
\text { and Universal Studios (purchased from Seagram). The company's water, waste management and } \\
\text { transport operations become Vivendi Environnement. }\end{array}$ \\
\hline 2001 & Edgar Bronfman Jr. resigns as vice-president of VU. \\
\hline 2002 & $\begin{array}{l}\text { VU acquires the entertainment assets of USA Networks and merges them with Universal Studios to } \\
\text { form Vivendi Universal Entertainment [VUE]. Assets are sold in publishing, Tele+, Canal+ Technologies, } \\
\text { Vinci, Vizzavi, EchoStar Communications, Vivendi Environnement. }\end{array}$ \\
\hline 2002 & Messier resigns and is replaced by Fourtou. \\
\hline 2003 & VU increases to $70 \%$ its ownership of the French telephone operator, Groupe SFR-Cegetel \\
\hline 2003 & $\begin{array}{l}\text { VU and General Electric [GE] combine the National Broadcasting Company [NBC] and VUE to form NBC } \\
\text { Universal [NBCU]. }\end{array}$ \\
\hline 2004 & $\begin{array}{l}\text { VU and GE agree to an } 80 \% \text { divestiture of VU's interest in VUE, and a concurrent acquisition of a } 20 \% \\
\text { interest in NBC. VU retains a } 20 \% \text { voting interest, and an } 18.5 \% \text { ownership interest, in NBCU. }\end{array}$ \\
\hline
\end{tabular}

Sources: Annual reports of Vivendi and Time Warner, Datamonitor, media industry profiles, business press reports. 
Table 2. VU Board of Directors in 2001

\begin{tabular}{|c|c|}
\hline Members & Positions \\
\hline \multicolumn{2}{|l|}{ French (12) } \\
\hline Jean-Marie Messier & CEO, VU \\
\hline Pierre Lescure* & CEO, Canal+ and Executive Officer of VU \\
\hline Eric Licoys & Executive Officer, VU \\
\hline Bernard Arnault* & CEO, LVMH Moët Hennessy Louis Vuitton \\
\hline Jean Louis Beffa* & CEO, la Compagnie de Saint-Gobain \\
\hline Jean Marc Espalioux & CEO, Accor \\
\hline Philippe Foriel-Destezet* & Founder, Ecco \\
\hline Jacques Friedman & CEO, UAP \\
\hline Henri Lachmann & CEO, Schneider Electric \\
\hline Serge Tchuruk & CEO, Alcatel \\
\hline René Thomas* & Honorary President, BNP Paribas \\
\hline Marc Viénot & Honorary President, la Société Générale \\
\hline \multicolumn{2}{|l|}{ Foreign (7) } \\
\hline Edgar Bronfman Jr. & CEO, VU Canada Inc \\
\hline Edgar M Bronfman & President, Samuel Bronfman Foundation, Inc \\
\hline Richard H Brown & President, Electronic Data Systems \\
\hline Esther Koplowitz & Reputedly the richest person in Spain \\
\hline Marie-Josée Kravis & Member, US Secretary of Energy's Advisory Board \\
\hline Samuel Minzberg & CEO, Claridge Inc. \\
\hline Simon Murray & Chair, Simon Murray and Associates (BVI) \\
\hline
\end{tabular}

* Directors who left the board prior to Messier's resignation. Source: VU annual report, 2001 
Table 3. Vivendi Board of Directors after Fourtou became CEO

\begin{tabular}{|c|c|c|}
\hline Members & Positions & Replacing \\
\hline \multicolumn{3}{|l|}{ French (6) } \\
\hline Jean-René Fourtou & $\begin{array}{l}\text { CEO, VU. Born south west France. Friend of Bébéar with whom he } \\
\text { managed UDF Party finances. Former member, Club Entreprises et Cités. } \\
\text { Graduate, Polytechnique }(X) \text {. }\end{array}$ & Messier \\
\hline Claude Bébéar & $\begin{array}{l}\text { Born south west France. Former CEO, AXA. Founder, Institut du mécénat } \\
\text { de solidarité, Institut Montaigne, and Club Entreprises et Cités. Graduate, } \\
\text { Polytechnique }(X) \text {. }\end{array}$ & Beffa \\
\hline Gérard Brémond & $\begin{array}{l}\text { CEO, Pierre et Vacances. Former member, Club Entreprises et Cités. Chair, } \\
\text { Lafarge. }\end{array}$ & Friedmann \\
\hline Bertrand Collomb & $\begin{array}{l}\text { President, Association Française des Entreprises Privées. Former member, } \\
\text { Club Entreprises et Cités. Graduate, Polytechnique (X), Corps des Mines }\end{array}$ & Espalioux \\
\hline $\begin{array}{l}\text { Dominique Hoenn* } \\
\text { Henri Lachmann }\end{array}$ & $\begin{array}{l}\text { CEO, BNP Paribas. } \\
\text { CEO, Schneider Electric. Former member, Club Entreprises et Cités. Friend } \\
\text { of Bébéar }\end{array}$ & Arnault \\
\hline \multicolumn{3}{|l|}{ Foreign (6) } \\
\hline $\begin{array}{l}\text { Edgar Bronfman Jr } ¥ \\
\text { Edgar Bronfman } ¥\end{array}$ & & \\
\hline Fernando F. de Córdova & Chair, René Barbier wine group & \\
\hline Paul Fribourg & CEO, ContiGroup. Member, Council on Foreign Relations. & Koplowitz \\
\hline Gerard Kleisterlee & CEO, Royal Philips Electronics Group & Viénot \\
\hline Marie-Josée Kravis & $\begin{array}{l}\text { Member, US Secretary of Energy's Advisory Board. Senior Fellow, Council } \\
\text { on Foreign Relations }\end{array}$ & $\begin{array}{l}\text { Foriel- } \\
\text { Destezet }\end{array}$ \\
\hline
\end{tabular}

* Dominique Hoenn resigned during 2003.

$¥$ The participation of Edgar Bronfman and Edgar Bronfman Jr. in any committees and Board meetings was suspended in May 2003 after the latter advised his intention to lead a consortium of potential purchasers of the American group assets. (VU Press release, 21 May 2003, http://www.amf-france.org/).

Source: VU's 2002 Annual Report. 
Table 4. Bronfman Family Presence on the Board of Directors of Vivendi (Universal)

\begin{tabular}{|l|l|l|l|}
\hline Year & $\begin{array}{l}\text { \% voting } \\
\text { shares }\end{array}$ & Bronfman family members & $\begin{array}{l}\text { Other directors with more } \\
\text { than 5\% of voting shares }\end{array}$ \\
\hline 2000 & 8.34 & $\begin{array}{l}\text { Edgar Bronfman Jr. } \\
\text { Edgar M Bronfman } \\
\text { Charles R Bronfman } \\
5 \text { other directors represented family interests } \\
\text { (8 of 20 directors) }\end{array}$ & None \\
\hline 2001 & 5.59 & $\begin{array}{l}\text { Edgar Bronfman Jr. } \\
\text { Edgar M Bronfman } \\
\text { (2 of 19 directors) }\end{array}$ & \\
\hline 2002 & 4.24 & $\begin{array}{l}\text { Edgar Bronfman Jr. } \\
\text { Edgar M Bronfman } \\
\text { (2 of 12 directors) }\end{array}$ & None \\
\hline 2003 & 0.47 & $\begin{array}{l}\text { Nil } \\
\text { (none of 10 directors)* } \\
\text { (none of 12 directors)* }\end{array}$ & None \\
\hline
\end{tabular}

* For four years, under the terms of a Shareholder Governance Agreement on June 19, 2000, the family was allocated three board seats if it held more than $75 \%$ of its initial participation; two seats if it held between $50 \%$ and $75 \%$; and one seat if it held between $25 \%$ and $50 \%$. This agreement gave the Bronfman shareholders incentive to act in concert like one shareholder (VU 2002 annual report).

Source: annual reports accessible at http://www.amf-france.org/

\section{Notes}

1 For a fuller understanding of the strong influence of the ENA and the 'old school' network in France, see Campbell (2014, p. 8).

${ }^{2}$ His father was a chartered accountant.

3 Vizzavi Portal added nearly 14 million subscribers to Canal+ in Europe, 8 million subscribers to the mobile network SFR, and 48 million subscribers to Vodafone mobile networks. 
${ }^{4}$ For example, music sold by Universal Music could be distributed on the Internet via Vizzavi and downloaded as a ringtone through SFR.

${ }^{5}$ Dickerson (2003: 1044-1048) provides a competing explanation for the removal of Messier. He points to concerns about the effrontery of a stock option proposal for senior executives, a breach of fiduciary duties by managers, and untested claims that 'VU's public documents were misleading [and that] Messier had systematically sought to hide the company's liquidity problems.'

${ }^{6}$ The Paris Match report on Messier in New York ('ça tourne rond à Manhattan', January 2002) showed him in Central Park and in his kitchen with his American collaborators. The French business elite regarded such a display as bad taste.

${ }^{7}$ Aileen Bronfman (1925 - 1986) was married to a prominent banker, Baron Alain de Gunzburg. Phyllis Bronfman (1927 - ) married a banker and cousin of the Rothschilds, was a generous benefactor, and was appointed Companion, Order of Canada (2001), Grand Officer, National Order of Quebec (2005), and Officier, Ordre des Arts et des Lettres de France. Edgar Bronfman (1929 - ) was elected president of the World Jewish Congress in 1981, and was awarded the U.S. Presidential Medal of Freedom in 1999. Charles Bronfman was Chair of several charitable foundations in Israel, the USA and Canada, was a Companion of the Order of Canada, and held honorary doctorates from universities in Israel, Canada and the USA. http://www.bronfmanfoundation.org/index.html; http://www.hillel.org/about/default; http://www.oxfordreference.com/view/10.1093/acref/9780199754687.001.0001/acref-9780199754687-e-25

\section{${ }^{8}$ http://www.tnova.fr/revue-de-presse/l-influence-des-think-tanks-cerveaux-des-politiques}

9 The Economist (4 July 2002, n.p.: 'Vivendi: A French Exception') is in little doubt about this. It asserts that Messier's 'eviction' from the role of CEO was because he 'was too French for the Americans and too American for the French' and that French business had an 'atavistic desire to retreat to its traditional clubbish ways.'

10 The CAC 40 index on January 2 was 4580.44 and 3669.24 on June 24. (NYSE Euronext website: http://www.euronext.com/trader/download/instrument-3047-FR-FR0003500008.html?selectedMep=1)

11 Le Monde, June 26, 2002 'La Bourse de Paris au plus bas depuis Septembre 2001' (http://www.lemonde.fr/). Soltani (2014 : 264) makes the unsubstantiated claim that 'The board of Vivendi Universal unanimously asked Messier to quit, and in July 2002 he stepped down.' 
${ }^{12}$ http://Ici.tf1.fr/economie/2002-07/top-chrono-pour-sauvetage-vivendi-4876183.html

${ }^{13}$ Our statement is based on the strategic decisions by Jean-René Fourtou as part of his rescue strategy. This strategy had been approved by most of the stakeholders, including the banks when they agreed to extend credit facilities to VU.

${ }^{14}$ This information is reported in many bibliographic sources.

15 'Jean-René Fourtou: un profil de redresseur', Le Figaro Economique, 2 July 2002, http://www.lefigaro.fr/

${ }^{16}$ http://www.lepoint.fr/actualites-societe/2007-01-19/le-pack-d-elite-de-rives/920/0/53106

17 The Economist (17 July 2003; 'The French Exception, Still Defended', n.p.) pointed to the day Messier declared 'French cultural exception is dead' as the 'day the French establishment turned on him.' Riding (2001, n.p.) noted that those in the French movie industry regarded his statement as a 'threat to their survival.'

${ }^{18} \mathrm{http}: / /$ www.veoliawater.com/search.htm?inp=vivendi\&c=0

19 'Jean-Marie Messier: les six mois de chute', Le Monde, 2 July 2002 http://www.lemonde.fr/

20 'Bronfman dynasty confronts its future', New York Times, 7 July 2002.

${ }^{21} \mathrm{VU}$ realized $€ 6.7$ billion from asset disposals in the second half of 2002, and €3 billion in 2003. 


\section{References}

Berle Jr A and Means G (1982) The Modern Corporation and Private Property. Buffalo, NY: Hein. Originally published by Macmillan in 1932.

Blaikie N (2007) Approaches to Social Enquiry. Cambridge (UK): Polity Press.

Bodie MT (2006) AOL Time Warner and the false god of shareholder primacy. Journal of Corporation Law 31: 975-1002.

Bourdieu P and Wacquant L (1992) Invitation to Reflexive Sociology. Cambridge: Polity Press.

Burch Jr PH (1981) Elites in American History. New York, NY: Holmes and Meier.

Burchell S, Clubb C, Hopwood A, Hughes J and Nahapiet J (1980) The roles of accounting in organizations and society. Accounting, Organizations and Society 5(1): 5-27.

Campbell M (2014) Hollande's old-school network brings France to its knees. The Australian, 14 April: 8.

Chabrak N (2011) The shareholder era and the changing nature of the corporation. A Comment on Managed by the Markets: How Finance Re-Shaped America by G. Davis (OUP, 2009). Accounting, Economics, and Law: A Convivium, 1 (2) Art. 4

Chabrak N (2012) Money talks: the language of the Rochester School. Accounting, Auditing \& Accountability Journal, 25 (3): 452-485.

Chan-Olmsted S and Chang B-H (2003) Diversification strategy of global media conglomerates: examining its patterns and determinants. Journal of Media Economics 16: 213-33.

Christopher J (2010) Corporate governance - A multi-theoretical approach to recognizing the wider influencing forces impacting on organizations. Critical Perspectives on Accounting 21: 683-95. 
Clark N (2004) In the shadow of Vivendi scandal, ex-chief works to clear name. New York Times June 28.

Clarke T (2007) International Corporate Governance: A Comparative Approach. London: Routledge.

Coatney M (2002) Person of the week: Jean-Marie Messier. Time 5 July.

Collinson D (2014) Dichotomies, dialectics and dilemmas: New directions for critical leadership studies? Leadership 10 (1) : 36-55.

Dahrendorf R (1972) Classes et Conflits de Classes dans la Société Industrielle. Paris: Mouton.

Davis F G (2009) Managed by the Markets: How Finance re-shaped America. New York, NY : Oxford University Press.

Dickerson C (2003) Ozymandias as community project: Managerial/corporate social responsibility and the failure of transparency. Connecticut Law Review 35: 1035-1072.

Eisenhardt K (1989) Agency theory: an assessment and review. Academy of Management Review 14: 532-550.

Galbraith J (1989) Le Nouvel Etat Industriel, Essai sur le Système Economique Américain. Paris: Editions Gallimard. (Original version: The new industrial state. New York, NY: Houghton Mifflin; 1968.)

Garcia-Murillo M and Maclnnes I (2001) FCC organizational structure and regulatory convergence. Telecommunications Policy 25: 431-452.

Giddens A (1976) New Rules of Sociological Method. London: Hutchinson.

Guieu G and Meschi P-X (2008) Conseils d'administration et réseaux d'administrateurs en Europe. Revue Française de Gestion 185: 21-45. 
Ignatius A (2014) The best-performing CEOs in the world, Harvard Business Review, November 2014: 1-15.

Jensen M and Meckling W (1976) Theory of the firm: managerial behavior, agency costs and ownership structure. Journal of Financial Economics 3: 305-60.

Kadushin C (1995) Friendship among the French financial elite. American Sociological Review 60: $202-21$.

La Porta R, Lopez-de-Silanes F and Schleifer A (1999) Corporate ownership around the world. Journal of Finance 54: 471-517.

Lukes S (2005) Power: A Radical View. New York: Palgrave.

Mace M (1971) Directors: Myth and Reality. Boston, MA: Harvard University Press.

Miles M and Huberman A (1994) Qualitative Data Analysis. London: Sage.

Morin F (2009) Transformation in the French model of shareholding and management. In: Clarke T and Chanlat J-F (eds.) European Corporate Governance: Readings and Perspectives. New York, NY: Routledge.

Orange M and Johnson J (2004) The Man Who Tried to Buy the World. London: Penguin.

Palmer D and Barber B (2001) Challengers, elites and owning families: a social class theory of corporate acquisitions in the 1960s. Administrative Science Quarterly 46: 87-120.

Palmer D, Barber B, Zhou X and Soysal Y (1995) The friendly and predatory acquisition of large U.S. corporations in the 1960s: the contested terrain. American Sociological Review 60: 469498.

Rebiere P (2004) Cas Vivendi Universal II - le Sauvetage. Case G1271. Paris: Centrale de Cas et de Médias. 
Riding A (2001) Remark by Vivendi chief unnerves French film industry. The New York Times, December 24, n.p.

Ron A (2008) Power: a pragmatist, deliberative (and radical) view. Journal of Political Philosophy 16: $272-92$.

Rowlinson M, Toms S and Wilson J (2006) Legitimacy and the capitalist corporation: crosscutting perspectives on ownership and control. Critical Perspectives on Accounting 17: 681702.

Rosenzweig P (2007) Misunderstanding the nature of company performance: the halo effect and other business delusions. California Management Review 49 (4): 6-20.

Shapiro S (2005) Agency theory. Annual Review of Sociology 31: 263-284.

Soltani B (2014) The anatomy of corporate fraud: a comparative analysis of high profile American and European corporate scandals. Journal of Business Ethics 120: 251-274.

Tourish D (2014) Leadership, more or less? A processual, communication perspective on the role of agency in leadership. Leadership 10: 79-98.

Van Knippenberg D, Sitkin S (2013) A Critical Assessment of Charismatic-Transformational Leadership Research: Back to the Drawing Board? The Academy of Management Annals $7(1): 1-60$.

Ward V (2002) Enemies in the boardroom. Vanity Fair October: 194-213.

Whittington R and Mayer M (2000) The European Corporation. New York, NY: Oxford University Press.

Yeo H-J, Pochet C and Alcouffe A (2003) CEO reciprocal interlocks in French corporations. Journal of Management and Governance 7: 87-108. 
Zajac E and Westphal J (1996) Who shall succeed? How CEO/board preferences and power affect the choice of new CEOs. Academy of Management Journal 39: 64-90.

Zeitlin M (1974) Corporate ownership and control: the large corporation and the capitalist class. American Journal of Sociology 79: 1073-1119.

Zeitlin M (1989) The Large Corporation and Contemporary Classes. New Brunswick, NJ.: Rutgers University Press. 